\title{
Effects of carrageenin on human synovial cells in vitro: morphology, hyaluronic acid production, growth, and the lysosomal system
}

\author{
B. J. ClarRis, J. R. E. FRASER, E. BAXTER, AND L. P. MALCOLM
}

From the University of Melbourne Department of Medicine, Royal Melbourne Hospital, Victoria, Australia

SUMMARY Some in-vitro effects of the arthritogenic polysaccharide carrageenin were studied on cells from human synovium. Synovial cells were isolated from intact human knee joints, and cell lines were developed by passaging with trypsin. Carrageenin was ingested by the cells but did not significantly affect cell growth, numbers of lysosomes, intracellular lysosomal enzyme activity $(\mathrm{N}$-acetyl- $\beta$-D-glucosaminidase), or release of lysosomal enzyme from cells. Carrageenin produced a reduction in net hyaluronic acid synthesis. It also induced a striking morphological change in a high proportion of synovial cells, characterised by increased spreading over the culture surface and apparent condensation of the cytoplasm into a pattern of ridges. Nonrheumatoid and rheumatoid synovial cells behaved similarly to one another.

The phytoextract carrageenin, when injected into foot pads or joints of certain animals, induces arthritis with many features of rheumatoid arthritis in man (Gardner, 1960; Muirden and Peace, 1969). Carrageenin has recently been used in rabbits to study processes occurring in synovial and cartilage tissue during induction of arthritis (Lowther and Gillard, 1976; Gillard and Lowther, 1976; Lowther et al., 1976). Cartilage was found to lose proteoglycans while lysosomal enzymes increased in the synovium. The contribution of the synovial intima to the total enzyme activity was uncertain and could not be distinguished from that of the infiltrating inflammatory cells, although the intimal cells show villous hyperplasia (Gardner, 1960) and considerable phagocytic activity in carrageenin arthritis (Muirden and Peace, 1969).

After discussion with Lowther and his colleagues it was decided to study the effects of carrageenin on synovial lining cells by utilising cells in culture, thus avoiding the secondary effects of inflammation.

\section{Materials and methods}

Cell types. Human synovial cells were isolated from cadaver joints by the procedure of Fraser and Catt

Accepted for publication 7 August 1978.

Correspondence to Dr B. J. Clarris, University of Melbourne, Department of Medicine, Royal Melbourne Hospital, PO, Victoria 3050, Australia.
(1961). Rheumatoid synovial cells were obtained from patients with persistent effusions (Clarris et al., 1977). Methods of management of synovial cell lines have been described previously (Fraser and McCall, 1965). Cell lines were used while in the euploid phase of their life history (Clarris and Fraser, 1967).

Human embryonic lung fibroblasts (MRC 5), isolated originally in the MRC Laboratories, Hampstead, London, were kindly supplied by Mrs J. Stanley, Commonwealth Serum Laboratories, Victoria, Australia.

\section{ULT URE}

Human serum was obtained aseptically from fasting donors. Fetal calf serum (FCS), Eagle's basal medium (EBM), trypsin and salt solution (Hanks's balanced salt solution-HBBS; Dulbecco phosphatebuffered saline PBS) were obtained from Commonwealth Serum Laboratories.

Carrageenin. Native (mixed $\lambda$ and $\chi$ ) carrageenin was kindly donated by Professor $D$. Lowther. Preparation, purification, and demonstration of biological activity have been described elsewhere (Lowther and Gillard, 1976). Stock solutions were prepared in saline or water and sterilised by boiling for 5 minutes.

Cell growth. Replica cultures were prepared in $\mathbf{5 0}$ $\mathrm{ml}$ polystyrene culture flasks (Falcon Plastics, $25 \mathrm{~cm}^{2}$ culture area). After 24 hours in 10 to $20 \%$ FCS, which allowed attachment and spreading, cultures 
were randomised and a group selected to determine initial numbers. The remainder were treated with test or control media, sealed and incubated at $37^{\circ} \mathrm{C}$ for predetermined periods. For final counting, cultures were rinsed with HBSS or PBS and trypsinised $(0.5 \%$ trypsin in PBS). Cell numbers were determined with a Coulter electronic cell counter.

\section{ENZYMES}

$N$-acetyl- $\beta$-D-glucosaminidase ( $N A G$ ase). Activity was determined in supernatants after centrifugation $(1400 \mathrm{~g}, 15 \mathrm{~min})$ and in cellular extracts prepared from cells in trypsin-saline suspension after counting. The method of assay was as described previously (Le Marshall, et al., 1977).

Lactic acid dehydrogenase ( $L D H)$. This was measured in culture supernatants with the facilities of the Department of Biochemistry, Royal Melbourne Hospital, by courtesy of Dr D. Campbell.

\section{HYALURONIC ACID}

Tritiated sodium acetate (Radiochemical Centre, Amersham, UK; $25 \mu \mathrm{Ci} / \mathrm{ml}$ ) was added to control and carrageenin-treated synovial cells in $20 \%$ FCS. After $72 \mathrm{~h}$ at $37^{\circ} \mathrm{C}$ supernatants were aspirated and frozen. Cells were counted with a Coulter counter. Hyaluronic acid was separated from proteins by density gradient ultracentrifugation in caesium chloride (density $\times 1.51 \mathrm{~g} / \mathrm{ml}$ ) by adapting the method of Silpananta et al. (1967) to tissue culture medium (Baxter et al., unpublished).

\section{Results}

UPTAKE OF CARRAGEENIN

Control and treated synovial cells were fixed in methanol and stained for $30 \mathrm{~min}$ with $0.1 \%$ alcian blue in $0.025 \mathrm{M}$ acetate-HC1 buffer ( $\mathrm{pH} \mathrm{5.7)} \mathrm{with}$ $0.7 \mathrm{M} \mathrm{MgCl}{ }_{2}$; alternatively with $0.1 \%$ toluidine $\overrightarrow{\overline{\mathrm{S}}}$ blue in $30 \%$ methanol. Stained particulate matter was observed inside many of the cells, indicating that carrageenin was ingested.

\section{MOR PHOLOGY}

Synovial cells in carrageenin-treated cultures spread $๗$ more widely on the culture surface and developed $\overrightarrow{0}$ a fenestrated appearance (Fig. 1). This seemed to be due to condensation of the cytoplasm into a pattern $\vec{\omega}$ of ridges. The onset of the phenomenon depended in part on carrageenin concentration but required at $\frac{\overrightarrow{0}}{0}$ least $16 \mathrm{~h}$. The effect occurred in fetal calf serum, $\omega_{\infty}$ human serum, or mixtures or both, whether fresh $\omega$ of heat-inactivated. The proportions of cells affected varied with individual cell lines and ranged from o $10-80 \%$ of the total, the maximum effect occurring 9 from 48-96 h. After removal of carrageenin the effect usually persisted for $24 \mathrm{~h}$, but most cells resumed normal morphology within the next $24 \mathrm{~h}$.

Carrageenin concentrations from $5 \mu \mathrm{g} / \mathrm{ml}-2 \mathrm{mg} / \mathrm{ml} \vec{\bullet}$ had no effect on the number or size of cytoplasmic $̋$ granules seen in synovial cells by phase contrast. At the highest concentrations ( 1 and $2 \mathrm{mg} / \mathrm{ml})$ synovial cells often developed irregular margins and sometimes clustered into groups but remained fully extended on the culture surface.

Human embryonic fibroblasts (MRC 5) showed no morphological responses to carrageenin $(50-500$ 을 $\mu \mathrm{g} / \mathrm{ml})$.

HYALURONIC ACID

Hyaluronic acid secretion was strongly inhibited by carrageenin (Table 1). A slight reduction occurred in total istopically labelled protein in the medium
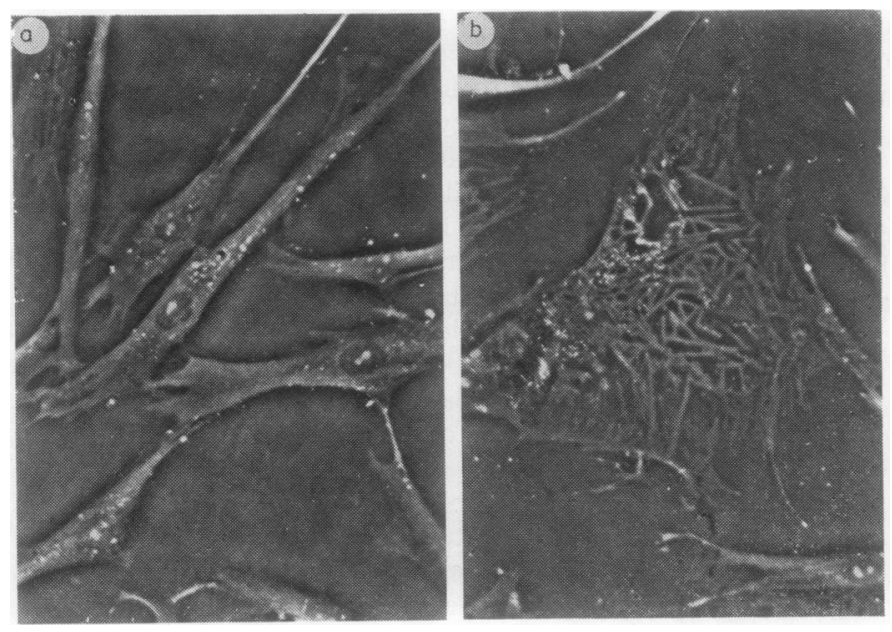

Fig. 1 Effect of carrageenin on morphology of human synovial cells: (a) untreated; (b) carrageenin-treated. Note increased spreading on the culture surface and apparent ridging of cytoplasm. Negative-medium phase contrast, $\times 400$. 
Table 1 Effect of carrageenin on production of hyaluronic acid by human synovial cells

\begin{tabular}{llll}
\hline Treatment & $\begin{array}{l}\text { Hyaluronic } \\
(\text { c.p.m./cell }) \\
(\text { mean } \pm S D)\end{array}$ & $\begin{array}{l}\text { Protein } \\
(\text { c.p.m./cell) } \\
(\text { mean } \pm S D)\end{array}$ & $\begin{array}{l}\text { Ratio HA/ } \\
\text { protein }\end{array}$ \\
\hline Control & $7.69 \pm 0.41$ & $4.41 \pm 0.62$ & 1.77 \\
$\begin{array}{l}\text { Carrageenin } \\
500 \mu \mathrm{g} / \mathrm{ml}\end{array}$ & $1.83 \pm 0.19$ & $3.58 \pm 0.23$ & 0.51 \\
\hline
\end{tabular}

Cells were grown for $72 \mathrm{~h}$ in EBM with $20 \%$ fetal calf serum. Cell numbers were determined with a Coulter electronic cell counter.

compared with untreated cells, possibly due to precipitation with carrageenin.

\section{GROWTH}

The effects of carrageenin on the multiplication of synovial cells were not statistically significant from untreated controls (Table 2).

\section{SUPRAVITAL STAINING}

As seen previously (Le Marshall et al., 1977), sucrose $(0.08 \mathrm{M})$ caused an increase in intracellular organelles, which fluoresced bright red with acridine orange. These particles have been identified as lysosomes (Allison and Young, 1964, 1969). However, carrageenin produced no differences from untreated controls.

\section{N-ACETYL- $\beta$-D-GLUCOSAMINIDASE}

Sucrose $(0.08 \mathrm{M})$ and carrageenin up to $500 \mu \mathrm{g} / \mathrm{ml}$ did not interfere with the enzyme assay. At higher

Table 2 Growth of synovial cells in carrageenin

\begin{tabular}{llll}
\hline Treatment & $\begin{array}{l}\text { No. of } \\
\text { observations }\end{array}$ & \multicolumn{2}{l}{ Ratio final count/initial count } \\
\cline { 2 - 4 } & & Range & Mean $\pm S D$ \\
\hline Control & 9 & $1.41-2.90$ & $2 \cdot 21 \pm 0.55$ \\
Carrageenin $50 \mu \mathrm{g} / \mathrm{ml}$ & 8 & $1.38-2.69$ & $2 \cdot 23 \pm 0 \cdot 52^{*}$ \\
Carrageenin $500 \mu \mathrm{g} / \mathrm{ml} 7$ & $1.74-2.61$ & $2 \cdot 10^{*} \pm 0.30^{*}$ \\
\hline
\end{tabular}

Experiments were for $72 \mathrm{~h}$ in EBM with $20 \%(\mathrm{v} / \mathrm{v})$ heat-inactivated human serum. *Not statistically significant (Wilcoxon matchedpairs signed-ranks test). concentrations carrageenin became inhibitory. Fetal calf serum possessed high background activity, but other available animal sera had inconsistent growthpromoting properties. Heat-inactivated human serum was therefore used throughout this part of the study.

As observed previously (Le Marshall et al., 1977), sucrose produced increased lysosomal enzyme activity in synovial cells but did not cause release into the medium (Table 3). Carrageenin did not produce any consistent difference in intra- or extracellular levels of NAGase during $72 \mathrm{~h}$ or longer periods of treatment.

In all of the above studies the responses of nonrheumatoid and rheumatoid synovial cells to carrageenin were identical.

\section{Discussion}

The morphological response of synovial cells to carrageenin was similar to the effect of dibutyryl cyclic AMP (DB cAMP) and other agents, which cause increase in endogenous cAMP (Fraser $e t$ al., 1979). Phase contrast and scanning electron microscopic observations in that study indicated that the apparent fenestration of cells was due to a pattern of cytoplasmic ridging. Electron microscopy of other cell types after cAMP shows aggregation of microfibrils around the microtubules (Willingham and Pastan, 1975), and the effect of carrageenin might therefore be due to alteration in the cytoskeletal structure related in some ways to change in endogenous cAMP levels.

Morphological changes in synovial cells induced by DB cAMP were accompanied by increased hyaluronic acid secretion (Fraser et al., 1979). Uptake of undegradable saccharides is usually followed by morphological and enzymic evidence of activation in the lysosomal system (Le Marshall et al., 1977). It therefore appears that subsequent events in both segments of cellular activity-endocytosis and lysosomal activation on the one hand and the specific

Table 3 Effect of carrageenin and sucrose on $N$-acetyl- $\beta$-D-glucosaminidase activity of human synovial cells

\begin{tabular}{|c|c|c|c|c|c|c|}
\hline \multirow[t]{3}{*}{ Treatment } & \multirow{3}{*}{$\begin{array}{l}\text { No. of } \\
\text { observations }\end{array}$} & \multicolumn{5}{|c|}{$N$-acetyl- $\beta-D$-glucosaminidase ${ }^{* *}$} \\
\hline & & Total & Ratio & $\begin{array}{l}\text { Treated } \\
\text { control }\end{array}$ & & Proportion excreted \% \\
\hline & & $M e a n \pm S D$ & \multicolumn{2}{|c|}{$\begin{array}{l}\text { Intracellular } \\
\text { Mean } \pm S D\end{array}$} & $\begin{array}{l}\text { Extracellular } \\
\text { Mean } \pm S D\end{array}$ & $M e a n \pm S D$ \\
\hline $\begin{array}{l}\text { Control } \\
\text { Carrageenin } 50 \mu \mathrm{g} / \mathrm{ml} \\
\text { Carrageenin } 500 \mu \mathrm{g} / \mathrm{ml} \\
\text { Sucrose }(0.08 \mathrm{M})\end{array}$ & $\begin{array}{l}8 \\
7 \\
7 \\
7\end{array}$ & $\begin{array}{l}176 \cdot 0 \pm 79 \cdot 6 \\
179 \cdot 9 \pm 78 \cdot 5 \\
182 \cdot 7 \pm 53 \cdot 7 \\
239 \cdot 6 \pm 93 \cdot 5\end{array}$ & \multicolumn{2}{|c|}{$\begin{array}{l}\overline{1 \cdot 01} \pm 0 \cdot 12 \\
1 \cdot 12 \pm 0 \cdot 18 \\
2 \cdot 11 \pm 0 \cdot 76^{*}\end{array}$} & $\begin{array}{l}- \\
0.98 \pm 0 \cdot 15 \\
0.96 \pm 0 \cdot 23 \\
0.94 \pm 0 \cdot 19\end{array}$ & $\begin{array}{l}49 \cdot 2 \pm 10 \cdot 8 \\
52 \cdot 7 \pm 12 \cdot 6 \\
46 \cdot 5 \pm 16 \cdot 5 \\
30 \cdot 6 \pm 10 \cdot 0\end{array}$ \\
\hline
\end{tabular}

Experiments were for $72 \mathrm{~h}$ in EBM with $20 \%(\mathrm{v} / \mathrm{v})$ heat-inactivated human serum. *Statistically significant $(\mathrm{P}<0.01$, Wilcoxon matched-pairs signed-rank test). ${ }^{* *} \mu \mathrm{g} p$-nitrophenol released from p-nitrophenol-2-acetamide-2-deoxy-D-glucopyranose per cell per h, $35^{\circ} \mathrm{C}$. 
cytoplasmic reorganisation associated with enhanced hyaluronic acid secretion on the other-are blocked in the initial stages of response after exposure to carrageenin. It is also possible that the apparent inhibition of cellular response does not extend to the secretion of neutral proteases, since other studies indicate that the lysosomal and neutral protease enzyme systems may respond independently after uptake of certain agents (Werb and Reynolds, 1974). Experiments are being considered to test these hypotheses.

The in-vitro results raise questions on the synovitis in carrageenin-induced arthritis in animals. The increased lysosomal enzymes in synovial tissue (Muirden and Peace, 1969) might arise specifically from the action of carrageenin on macrophages in the synovium (Allison et al., 1966) or be secondary to inflammation triggered by carrageenin in some other way. Carrageenin was found in this and other studies (Turner and Magnusson, 1962) to precipitate with some serum proteins and would be expected to come out of solution in synovial fluid. Inflammation might be initiated by phagocytosis of carrageenin-protein complex by leucocytes in the synovial fluid, with subsequent discharge of degradative enzymes (Weissmann et al., 1972; Oronsky et al., 1973). It is also possible that aggregated protein in the complexes might evoke an autoimmune response. Rheumatoid-factor like antibodies have not been sought in carrageenin-treated animals, but the synovial infiltration is characterised by lymphocytes and plasma cells similar to the pattern in rheumatoid arthritis (Muirden and Peace, 1969).

This work was supported by a grant from the National Health and Medical Research Council of Australia.

\section{References}

Allison, A. C., Harington, J. S., and Birbeck, M. (1966). An examination of the cytotoxic effects of silica on macrophages. Journal of Experimental Medicine, 124, 141-154.

Allison, A. C., and Young, M. R. (1964). Uptake of dyes and drugs by living cells in culture. Life Sciences, 3, 1407-1414.

Allison, A. C., and Young, M. R. (1969). Vital staining and fluorescence microscopy of lysosomes. In Lysosomes in Biology and Pathology, Vol. 2, p. 600. Edited by J. T. Dingle and H. B. Fell. North Holland: Amsterdam.

Clarris, B. J., and Fraser, J. R. E. (1967). Relationship between chromosomal changes and alterations in the behaviour of a strain of human synovial cells during its life history in vitro. Annals of the Rheumatic Diseases, 27, $\frac{\square}{\infty}$ 597-603.

Clarris, B. J., Fraser, J. R. E., Moran, C. J., and Muirden, K. D. (1977). Rheumatoid synovial cells from intact joints: morphology, growth and polykaryocytosis. Annalis of the Rheumatic Diseases, 36, 293-301.

Fraser, J. R. E., and Catt, K. J. (1961). Human synovial cell $\overline{\bar{c}}$ culture. Use of a new method in a study of rheumatoid $\vec{\nabla}$ arthritis. Lancet, 2, 1437-1439.

Fraser, J. R. E., and McCall, J. F. (1965). Culture of synovial cells in vitro. Annals of the Rheumatic Diseases, 24, 351-359.

Fraser, J. R. E., Clarris, B. J., and Baxter, E. (1979). Patterns $\vec{O}$ of induced variation in the morphology, hyaluronic acid $\vec{\overrightarrow{ }}$ and secretion, and lysosomal enzyme activity of cultured $\vec{\omega}$ human synovial cells. Annals of the Rheumatic Diseases, 38, 000-000.

Gardner, D. L. (1960). Production of arthritis in the rabbit? by the local injection of the mucopolysaccharide carag- $\infty$ heenin. Annals of the Rheumatic Diseases, 29, 369-376. $\omega$

Gillard, G. C., and Lowther, D. A. (1976). Carrageenin-ĩ induced arthritis. II. Effect of intraarticular injection of of carrageenin on the synthesis of proteoglycan in articular cartilage. Arthritis and Rheumatism, 29, 918-922.

Le Marshall, J., Fraser, J. R. E., and Muirden, K. D. (1977). Lysosomal activation by neutral saccharides in cell cultures of synovium. Annals of the Rheumatic Diseases, $\bar{\Phi}$ 36, 130-138.

Lowther, D. A., and Gillard, G. C. (1976). Carrageenin- $\vec{\bullet}$ induced arthritis. I. The effect of intraarticular carrageenin 6 on the chemical composition of articular cartilage. Arthritis and Rheumatism, 19, 769-776.

Lowther, D. A., Gillard, G. C., Baxter, E., Handley, C. J., and Rich, K. A. (1976). Carrageenin-induced arthritis. III. Proteolytic enzymes present in rabbit knee joints after a single intraarticular injection of carrageenin. Arthritis and $\frac{\mathrm{O}}{\mathrm{Q}}$ Rheumatism, 19, 1287-1294.

Muirden, K. D., and Peace, G. (1969). Light and electron $\overrightarrow{\vec{F}}$ microscope studies in caragheenin, adjuvant and tuberculin- $\mathrm{O}$ induced arthritis. Annals of the Rheumatic Diseases, 28, $392-401$.

Oronsky, A., Ignarro, I., and Perper, R. (1973). Release of cartilage mucopolysaccharide-degrading neutral protease from human leukocytes. Journal of Experimental Medicine, $\bar{Q}$ 138, 461-472.

Silpananta, P., Dunstone, J. R., and Ogston, A. G. (1967). Fractionation of a hyaluronic acid preparation in a density gradient. The isolation and identification of a chrondoitin $\bigcirc$ sulphate. Biochemistry Journal, 104, 404-409.

Turner, K. J., and Magnusson, G. J. (1962). Carrageenin as a 0 protein precipitant. Nature, 194, 451-452.

Werb, Z., and Reynolds, J. J. (1974). Stimulation by endo $\frac{D}{D}$ cytosis of the secretion of collagenase and neutral proteinase from rabbit synovial fibroblasts. Journal of Experi- N mental Medicine, 140, 1482-1497.

Weissmann, G., Zurier, R. B., and Hoffstein, S. (1972). N Leukocytic proteases and the immunologic release of lysosomal enzymes. American Journal of Pathology, 68, $\omega$ 539-559.

Willingham, M. C., and Pastan, I. (1975). Cyclic AMP and cell morphology in cultured fibroblasts. Journal of Cell Biology, 67, 146-159. 